\title{
The Iliad, the Odyssey, and narratological intertextuality*
}

\author{
Bruno Currie
}

\section{Abstract}

This paper discusses four distinctive Homeric narrative features where an intertextual relationship between the Iliad and the Odyssey can be discerned: (1) the narrator's choice to begin the narration mid-fabula, pitching the narratee in medias res; (2) the narrator's initial declaration of a theme in the proem and the subsequent duplication of that theme in the course of the narrative; (3) the creation of a sense of narrative closure through scenes involving fathers, and a related use of fathers as unseen characters in the narrative; and (4) the use of interlaced storylines and of a related continuity of time principle. The poet of the Odyssey must be understood on several occasions to recur not to any quasi-transcendental repertory of narratological techniques, but to the narratological techniques that were specifically deployed in the Iliad.

\section{Introduction}

This paper is concerned with diachronic narratology at its minimum extension: two poems at the start of the extant Greek epic tradition very probably composed within a generation of each other and possibly by the same poet. ${ }^{1}$ Here, therefore, the spotlight is not, as in other papers in this collection, on how a single narratological feature evolved through a long succession of poets 'from Homer to Nonnus', but on whether a cluster of narratological, or more broadly narrative, ${ }^{2}$ features can plausibly be seen as a vehicle for intertextuality between two closely related epic poems.

The intertextuality of the Iliad and Odyssey can be variously conceived. ${ }^{3}$ I will be understanding it as a matter of the Odyssey responding to the Iliad as a largely fixed text ${ }^{4}$ and

\footnotetext{
* I am grateful to the participants in the conference at Oslo in June 2016 for constructive feedback on this paper.

${ }^{1}$ Possibly by the same poet: e.g. Janko 2012, 28, 33; Wachter 2012, 65-6. Differently, M. L. West 2014, 1, 44.

2 Throughout I have taken 'narratology' in the 'broad sense' advocated by de Jong 2001, p. vii; 1997, 305.

${ }^{3}$ Or denied outright: Page 1955, 157-9.
} 
as not radically different in kind from the intertextuality obtaining between the Iliad and later poems in the Greek epic tradition (say Apollonius' Argonautica or Quintus' 'Posthomerica'), even though the balance between oral and written in both the composition and the reception of the poems is assuredly very different. ${ }^{5}$ The posterity of the Odyssey to the Iliad is here also assumed. ${ }^{6}$ On another view, the Iliad and the Odyssey are seen as being equally aware of the other, the interaction being taken to be one between synchronous poetic traditions rather than specific texts. ${ }^{7}$ That view precludes a diachronic narratological approach to the Iliad and the Odyssey, and is thus at odds with the premise of this paper. I have indicated certain objections to this view elsewhere. ${ }^{8}$

The investigation into the intertextuality of the Iliad and the Odyssey has been frequently conducted from thematic and phraseological points of view. ${ }^{9}$ Yet the question of whether the Odyssey can plausibly be said to quote the Iliad in terms of narratology or its presentation of the story has rarely been explored in any sustained way. ${ }^{10}$ The term narratological intertextuality naturally encourages conclusions relating both to narratology (specifically, in its historical, diachronic, aspect) and to intertextuality (here, between the Iliad and the Odyssey). This study will duly attempt to draw both kinds of conclusion, though the latter will be found to preponderate somewhat.

My discussion will centre on four distinctive Homeric narrative features where a case for intertextuality between the Iliad and the Odyssey can plausibly be made. (Distinctive, because often there are indications that other early Greek epic - such as the poems of the Epic Cycle or the apparently non-Homeric Doloneia - handled these features very differently.) These are as follows.

\footnotetext{
${ }^{4}$ Cf. Rengakos 2002, 174 'die Übernahme der Iliasreminiszenzen [ist] so spezifisch, daß man davon auszugehen hat, daß das ältere Epos bereits schriftlich fixiert in der uns bekannten Form dem jüngeren Dichter vorgelegen hat, daß $\mathrm{m}$ [it] a[nderen] W[orten] zwischen beiden Epen ein durchaus als "intertextuell" zu bezeichnendes Verhältnis besteht.' Cf. Usener 1990, 207-8, 210.

${ }^{5}$ See Currie 2016, esp. 4-29.

${ }^{6}$ Cf. Currie 2016, 39-40.

7 e.g. Nagy 1979, 42-3, cf. 8, 41; Pucci 1987, 18 and passim; Marks 2008, 9.

${ }^{8}$ Currie 2016, esp. 15-18.

${ }^{9}$ Usener 1990; Rutherford 2001 (1991-3); Saïd 2011, 373-9; M. L. West 2014, 70-6; Schein 2016, 81-91; Currie 2016, 39-47, 224-7.

${ }^{10}$ Attention should be drawn to de Jong 2002, esp. p. 77: 'The aim of the present paper is... to discuss the way in which the Odyssey takes up and develops narrative techniques from the Iliad. In this way I hope to demonstrate that narratology can be fruitfully employed for the writing of literary history.'
} 
(1) The narrator's choice to begin the narration mid-fabula, pitching the narratee 'into the midst of the action' (Horace, Ars poetica 148-9). ${ }^{11}$

(2) The narrator's initial declaration of a theme in the proem, and the subsequent duplication of that theme in the course of the narrative.

(3) The creation of a sense of narrative closure through scenes involving fathers, and a related use of fathers as unseen characters in the narrative.

(4) The use of interlaced storylines and of a related continuity of time principle.

It is worth underlining here another important difference of this approach from the investigation of a single narratological device throughout the Greek epic tradition: we will for the most part not be dealing with formal narratological devices per se, but with narratological (or narrative) devices as they are attached to very similar narrative content in both poems. It will also be obvious that this approach fixes on commonalities of narrative technique in the two poems. It is also possible, of course, to be struck by narrative differences between the two poems. ${ }^{12}$ However, I take the similarities in general to create a case for intertextuality that is not undone by the differences. ${ }^{13}$

\section{The in medias res approach}

I start with a coarse-grained and trite observation: the narratives of both the Iliad and the Odyssey plunge their narratees in medias res, respectively carving out a story of 51 and 41 days from an underlying traditional mythological fabula of 10 and 20 years, ${ }^{14}$ a story that nevertheless reverberates with the whole underlying mythological fabula. This constitutes a striking contrast, noted already by Aristotle and Horace, to what we know of the Cyclical epics, especially the Cypria and Little Iliad. ${ }^{15}$

There can be more fine-grained aspects to this observation. Consider the following two passages, Il. 2.300-332 and $O d .2 .163-176$ :

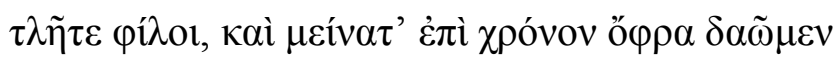

\footnotetext{
${ }^{11}$ De Jong 2014, 88.

12 e.g. Schein 1997, 348-9; Rutherford 2013, 82.

${ }^{13}$ Cf. Currie 2016, 174.

${ }^{14}$ De Jong 2007, 19; Rengakos 2002, 173; Nünlist 2009, 88; cf. Lowe 2000, 106 and 131; Hellwig 1964, 40-5.

15 Aristot. Poet. 1451a16-35; Hor. AP 136-52. See Rutherford 2001 (1991-1993), 127; Rengakos 2002, 173-4; 2015, 155-6. (But note that the Aethiopis and Iliou persis also appear to be 'dramatic' compositions, their plots limited to a few days: Rengakos 2015, 161-2.)
} 


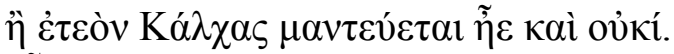

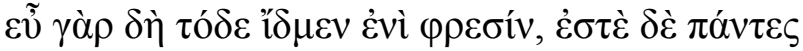

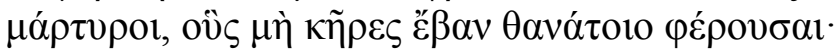

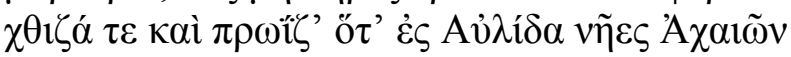

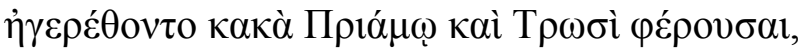

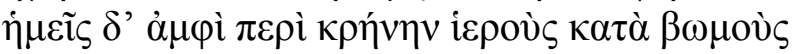

305

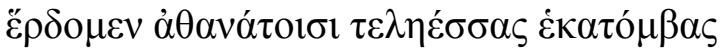

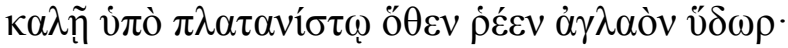

ह้ $\theta^{\prime}$ ' $\dot{\varepsilon} \varphi \alpha ́ v \eta \mu \dot{\varepsilon} \gamma \alpha \sigma \tilde{\eta} \mu \alpha \cdot \ldots$

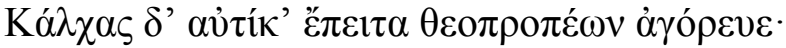

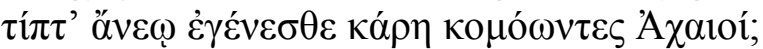

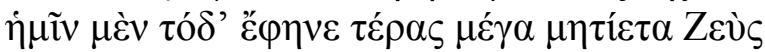

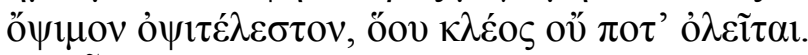

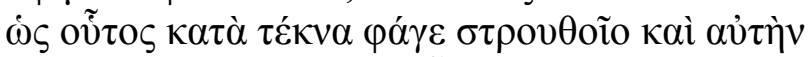

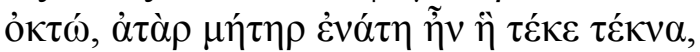

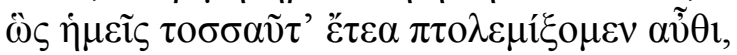

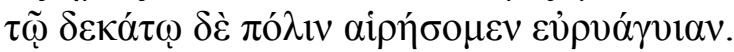

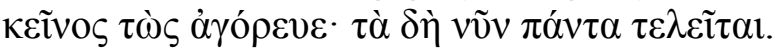

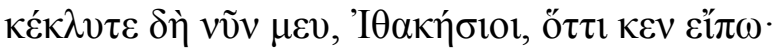

(Il. 2.300-332) $)^{16}$

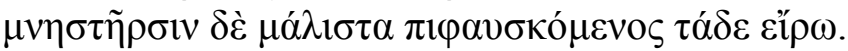

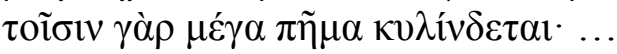

...

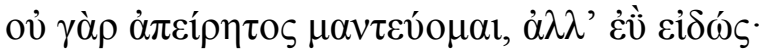

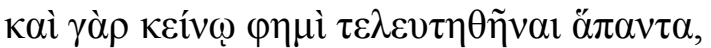

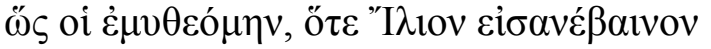

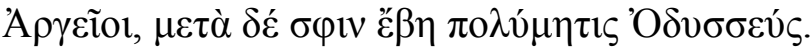

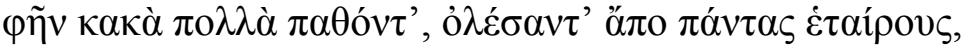

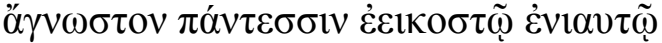

325

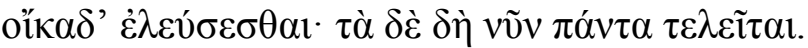

$(\text { Od. } 2.163-176)^{17}$

\footnotetext{
16 “"Take heart, comrades, and stay put until such time as we may learn whether Kalchas prophesies truly or not. For we know this well in our hearts, and you were all witnesses, those whom the fates of death have not borne away; it seems like only yesterday when the ships of the Achaeans were being assembled at Aulis, bearing troubles to Priam and the Trojans, and we around the spring by the sacred altars were sacrificing agreeable hecatombs to the gods beneath the pleasant plane-tree, whence the splendid water flowed. Then a great portent appeared... Thereupon Kalchas straightaway spoke, revealing the will of the gods: 'Why, o long-haired Achaeans, have you fallen silent? Shrewd Zeus has shown this great portent to us, late-working and of late fulfilment, whose fame will never perish. Just as he [the snake] devoured the children of the sparrow, and her herself, eight of them, and the mother who bore the children was the ninth, so we shall wage war for as many years there, and in the tenth shall capture the city of the broad streets." That's how he spoke; and now all these things are coming to pass.'

17 "'Listen now, men of Ithaca, to what I have to say; it is to the suitors in particular that I open up and say these things; for a great misfortune is coming their way.... It's not in ignorance that I prophesy, but knowing full well; for I declare that everything is coming about for that man [Odysseus] as I stated it to him when the Argives were embarking for Troy. I said he would suffer many hardships, lose all his companions, and unrecognized by all only in the twentieth year come home; and now all these things are coming to pass.",
} 
In both passages secondary narrators, Odysseus and Halitherses, speaking in the tenth and twentieth years of the fabula respectively, recall a prophecy at the very start of the fabula and anticipate the imminent conclusion of the fabula. Odysseus recalls Kalchas prophesying to the Achaeans at the start of the campaign that they would sack Troy in the tenth year; Halitherses recalls himself prophesying to Odysseus at the start of the campaign that the latter would return home in the twentieth year. The Iliad's narratologically intricate treatment of the omen-at-Aulis episode (employing character-text with flashback) contrasts with the apparently limpid handling of the same episode in the narrative of the Cypria (employing narrator-text without flashback). The Iliad's treatment of this episode springs from its distinctive approach to its fabula (the in medias res approach, 'reverberation'), and it is this that gets replicated precisely in the Odyssey. ${ }^{18}$ Here, therefore, the Odyssey might reasonably be said to quote in nuce the Iliad's whole narratological approach to its material. In a characteristic complimentary-cum-competitive gesture, the Odyssey-poet would signal that his poem is conceived along the same naarratological lines as the Iliad. The argument for a narratological intertextuality here can be matched by arguments also on the thematic and phraseological levels. ${ }^{19}$

We should compare also the following passage of Quintus' Posthomerica:

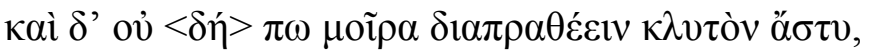

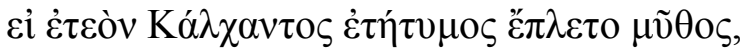

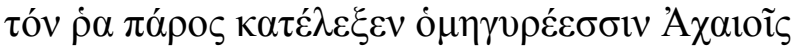

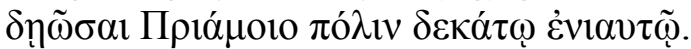

(Q. S. 8.475-7) $)^{20}$

Nestor (this time) recalls for the Achaeans Kalchas' prophecy at Aulis. But simultaneously Quintus' use of character-text and flashback in this passage recalls for us, his readers, the

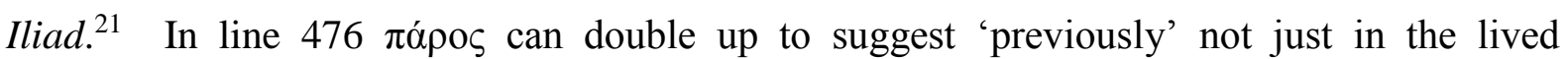
experience of the characters in the poem, but also in the experience of Quintus' readers, who have in their own way encountered Iliad 2.323-9 'before'. ${ }^{22}$

\footnotetext{
${ }^{18}$ For the handling of the 'omen at Aulis' episode in the Cypria, see Cypria, argumentum Procli p. 40.33-35 Bernabé; Ps.-Apollod. Epit. 3.15, Ov. Met. 12.11-23.

${ }^{19}$ See Currie 2016, 40-2.

20 "'It is not yet our fate to sack the renowned city, if truly Kalchas' speech was true, which previously he recounted to the assembled Achaeans, that they would raze the city of Priam in the tenth year."'

${ }^{21} \mathrm{Cf}$. Schmitz 2007, 79, noting the 'complex anachrony' common to the passages of Homer and Quintus.

${ }^{22}$ See similarly (on Q.S. $1.9 \pi \rho$ «
} 
A narratologically idiosyncratic passage of the Iliad, relying on the Iliad's distinctive in medias res approach to the fabula, thus arguably gets quoted successively by the Odysseypoet and by Quintus; unlike the Posthomerica, however, the Odyssey does not merely pay intertextual homage to the Iliad's in medias res approach in an isolated passage, but replicates that approach in its own narrative. Both the Odyssey-poet and Quintus appear to express their appreciation that the in medias res approach is a hallmark of the Iliad, no less than Aristotle and Horace, though in a poet's, rather than a critic's, idiom.

\section{Duplication of the poem's theme}

The Iliad, we have seen, eschews a narrative of the whole Trojan War in favour of a more restricted theme, the anger of Achilleus. Not only does this restricted theme metonymically stand for a narrative of the whole war (for instance, Achilleus' retribution against Agamemnon for the abduction of Briseis reverberates with the wider theme of the retribution of the Atreidai against Paris for the abduction of Helen), but the restricted menistheme of the Iliad, announced in its first word, itself transpires in the course of the narrative to be duplex: the theme of Achilleus' anger against Agamemnon for the abduction of Briseis, which drives the narrative in books 1-16, gives way to the theme of Achilleus' anger against Hektor for the killing of Patroklos, which drives the narrative in books 18-24. There was no inkling in the proem of this development to come. But carefully constructed parallel scenes (or if we wish, intratextuality) make it clear that the anger against Hektor parallels the anger against Agamemnon: Achilleus rejects the compensation proffered by Hektor in book 22 in terms very similar to those in which he rejected the compensation proffered by Agamemnon via the embassy of book 9 (Il. 9.378-87, 22.349-54). ${ }^{23}$ We appear to be dealing with a very deliberate duplication of the poem's theme, and to the extent that it implied a simple menistheme, the proem therefore misdirects us.

This whole narrative situation is suggestively replicated in the Odyssey. The restricted theme of the final stage of Odysseus' homecoming also manages to take in the wider themes of Odysseus' whole nostos (in the Apologue of books 9-12), as well as the nostoi of the other Achaeans (most recurrently, of Agamemnon), through a technique of

${ }^{23}$ Macleod 1982, 20-1; Griffin 1995, 120. 
'flashback', rather than the Iliad's more oblique technique of 'reverberation'. ${ }^{24}$ And the Odysseus-nostos-theme of the Odyssey (signalled in the proem, Od. 1.5 and 9, and, just outside it, $O d .1 .13$ and 17) ${ }^{25}$ also emerges as duplex: the theme of Odysseus' return to Ithaca gives way to the theme of Odysseus coming into full possession of his own oikos. ${ }^{26}$ Again,

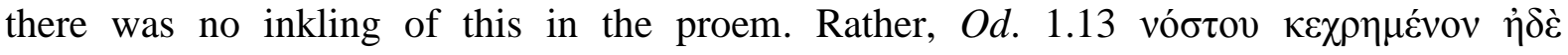
rovaıkó $\varsigma^{27}$ implied, if anything, that homecoming and reunion with Penelope would be synonymous and simultaneous, not successive, events. ${ }^{28}$ Once again, intratextuality makes it clear that the reunion with Penelope consciously parallels the homecoming: the reunion of Odysseus and Penelope is marked with a shipwrecked sailor simile (Od. 23.233-40) that pointedly inverts the simile used to convey the effective end of Odysseus' storm-tossed wanderings in his arrival at Scheria (Od. 5.394-9). ${ }^{29}$

It would be possible to see the Odyssean theme of Odysseus' successful nostos as an intertextual response to the theme of Achilleus' loss of nostos in the Iliad. ${ }^{30}$ Accordingly, the Odyssey's duplication of its nostos theme may be seen as a response to the Iliad's duplication of its menis-theme: the result of imitatio rather than of coincidence (independent development, the working of tradition, or even the same poet working unconsciously in the same way). There are indeed grounds for thinking that the Odyssey-poet was in general sensitive to the Iliad's duplication of the menis theme. Consider Od. 22.60-4, a passage regarded by several as one of the clearest instances of Odyssean allusion to the Iliad: ${ }^{31}$

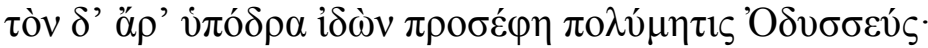

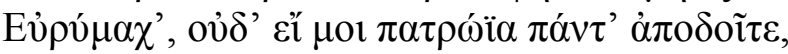

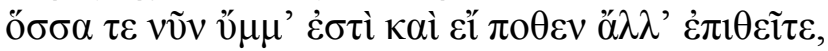

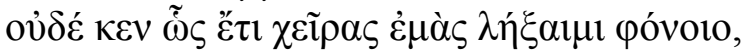

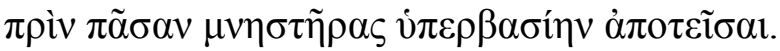

\footnotetext{
${ }^{24}$ On Odyssean 'flashback' (in embedded stories) versus Iliadic 'reverberation', see Rengakos 2015, 156; 2002, 177; cf. de Jong 2002, 79 (using the term 'projection' for 'reverberation').

${ }^{25}$ Jones 1988,1 'it is more profitable to regard the proem as including 11-21.' On the elliptical nature of the proem proper, see Lowe 2000, 151-2.

${ }^{26}$ Cf. Lowe 2000, 142; Hellwig 1964, 20 'Jetzt ist [Odysseus] im inneren Sinn heimgekehrt'.

27 'Desirous of his homecoming and his wife.'

${ }^{28}$ Macleod 1982, 21 and n. 2. Rutherford 2001 (1991-3), 128 'The most striking thing... is that in both the Iliad and the Odyssey that statement embraces only part of the poem's full scope: in the Iliad, the poet announces that his subject will be the wrath of Achilles against Agamemnon, but does not give any hint of the later wrath against Hector, and its cause and consequences... In the Odyssey, the proem refers to the journeyings and homecomings of the hero without his companions, but in such a way as to suggest that his arrival home is the poet's main goal; there is as yet no mention of the fresh sufferings which await him in his own country.'

${ }^{29}$ De Jong 2001, 559-60; Currie 2016, 260.

${ }^{30}$ Cf. Rutherford 2001 (1991-3), 132-5; Rengakos 2002, 186.

${ }^{31}$ Rutherford 2001 (1991-3), 130; N. J. Richardson 1993, 141-2; Schein 2016, 85-90; Currie 2016, 45-6.
} 
Here Odysseus rejects Eurymachos' proffered recompense in terms that recall and conflate Achilleus' rejection of Agamemnon's proffered recompense in Iliad IX and his rejection of Hektor's offered recompense in Iliad XXII. I suggested earlier that the parallelism, or intratextuality, between precisely these two Iliadic scenes signalled the Iliad-poet's selfawareness about his duplication of the menis-theme. By the same token, the Odyssey-poet's intertextual conflation of the two scenes might be taken both to signal and to build on his awareness of the equivalence in the Iliad of Achilleus' anger against Hektor and his anger against Agamemnon; in other words, to signal and to build on his awareness of the Iliad's duplication of its menis-theme. ${ }^{33}$

Od. 22.61-6 is a well-known, and strong, candidate for allusion by the Odyssey to the Iliad. We may consider in its light a more tenuous one that also arguably exploits awareness of the Iliad's duplication of its menis-theme. In Odyssey XXIII, ruminating on the consequences of having killed the suitors, Odysseus says the following to Telemachos:

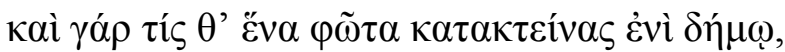

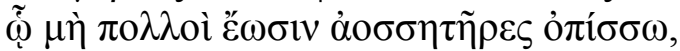

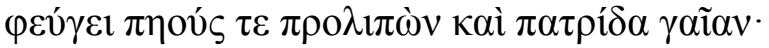

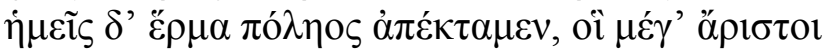

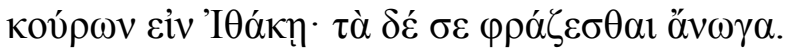

$(\text { Od. 23.118-22) })^{34}$

Compare this with what Aias says to Achilleus in the Iliadic Embassy about the latter's attitude towards Agamemnon:

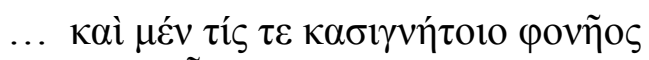

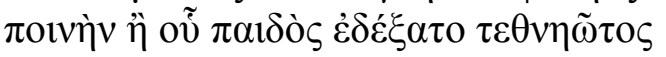

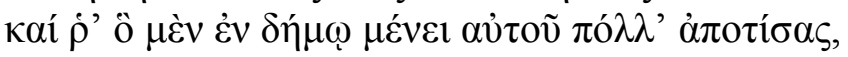

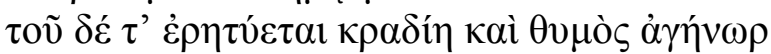
635

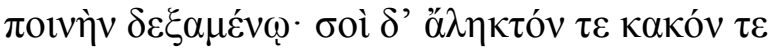

\footnotetext{
32 'Looking darkly, much-scheming Odysseus addressed him: "Eurymachos, not even if you were to repay me with all your ancestral property, both all that you have now and whatever you could add from elsewhere, not even so would I stay my hands from killing until I have repaid the suitors in full for their transgression."”

${ }^{33}$ Compare what we might want to say about the relationship of the Aeneid with the Iliad and Odyssey. Turnus' supplication of Aeneas at the end of Aeneid XII is intertextual with both Iliad XXII (Hektor's supplication of Achilleus) and Iliad XXIV (Priam's supplication of Achilleus); Virgil thus recognizes and exploits the intratextuality of the two Iliadic scenes. Likewise, Aeneas' arrival in Libya in Aeneid I is intertextual with both the Phaeacian narrative of Odyssey V-VII and the Ithacan narrative of Odyssey XIII; Virgil again recognizes and exploits the intratextuality of the two Odyssean scenes.

34 "'For someone who has killed a single man in his community, a man who does not have many avengers surviving him, goes into exile, leaving behind his in-laws and his ancestral land; yet we have killed the bulwark of the city, those who are by far the best of the young men in Ithaca: I ask you to reflect on that."'
} 


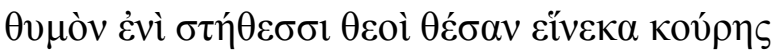

oins.

$(\text { Il. } 9.632-8)^{35}$

If this is an intertextual echo, it seems a weak one, not at all easy to interpret. It is not $(\text { primarily })^{36}$ a matter of repeated phraseology, but rather of repeated ideas and a certain

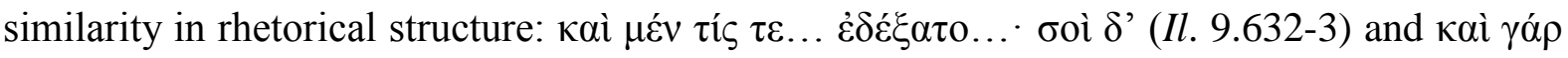

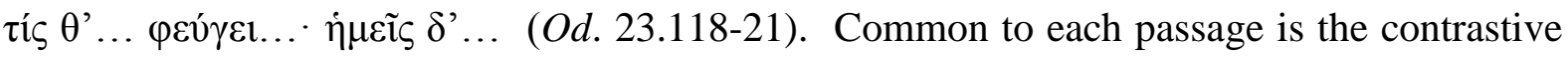
use of an example of a homicide in an a fortiori argument from the situation of an anonymous

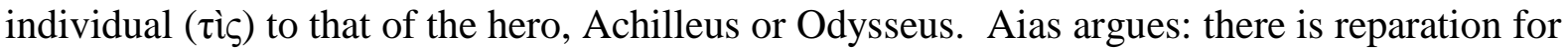
the killing of a brother or a son; so much the more ought there to be from Achilleus for Agamemnon's temporary taking of 'a mere girl'. Odysseus argues: somebody who has killed even one person, even lacking powerful connections, does not stay in his fatherland; so much the worse are their prospects of staying in Ithaca after killing the cream of Ithacan society. There are seemingly pointed reversals here. ${ }^{37}$ Aias invokes an image of a homicide who comes to an accommodation with the victim's relatives and does not need to go into exile; Odysseus invokes an image of a homicide unable to come to any such accommodation who must go into exile. In Aias' comparison, Achilleus is likened to the kinsman of the murdered person; in his own comparison, Odysseus is likened to the homicide. Further to these reversals, there is what we may call an intensification in the image: while Achilleus' situation in the narrative is merely compared to that of homicide and victim's kinsmen, Odysseus' situation in the narrative is identical to that of homicide and victims' kinsmen. The fate of a homicide is a recurring motif in early Greek epic and doubtless a recurring reality in early Greece, and both scenarios, exile and an accommodation with the victim's kin, were surely common enough. However, it seems inadequate to consider each passage entirely independent uses of conventional images of homicides couched in a conventional rhetorical

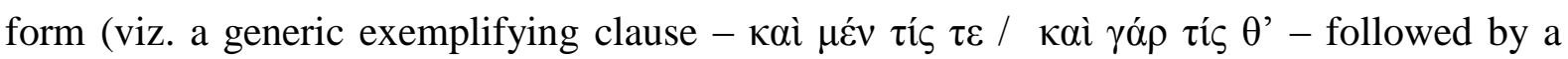
focussing clause with a personal pronouns, $\sigma o \grave{~} \delta$ ' / $\left.\dot{\eta} \mu \varepsilon i \tilde{\varsigma} \delta^{\prime}\right)$.

Judged solely on thematic-phraseological grounds, this candidate for Odyssean allusion to the Iliad may seem borderline. But consider this example in the context of the

\footnotetext{
35 "'Someone accepts compensation from the murderer when his brother or son has been killed and he remains there in the community once he has made rich amends, and the other's heart and manly spirit is restrained after he has accepted the compensation. But the gods have made your anger unceasing and evil, for the sake of a mere girl.'”

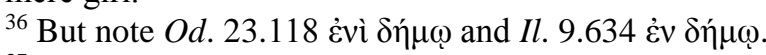

${ }^{37}$ See Currie 2016, General Index s.v. 'reversals'.
} 
Iliad's duplicated menis-theme, and the Odyssey's putative response to the Iliad's duplicated menis-theme. In the Embassy, in the context of Achilleus' anger against Agamemnon, Aias' appeal falls on deaf ears: Achilleus does not accept Agamemnon's proffered compensation. However, in the Ransoming of Hektor, in the context of Achilleus' anger against Hektor, Achilleus does accept Priam's compensation. There, in a famous simile, Priam is likened to a fugitive homicide finding refuge with a rich man:

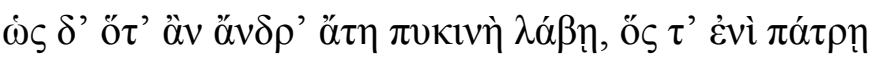

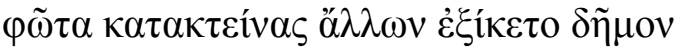

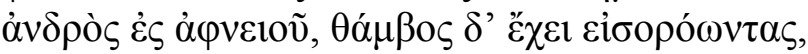

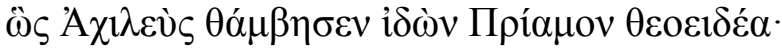

(Il. 24.480-2) $)^{38}$

In this celebrated contrast-simile, tenor and vehicle are strikingly mismatched: in the narrative, Achilleus is a killer and Priam a rich man. Yet the simile also seems curiously appropriate once we recognize that this is the second time in the poem that the angry Achilleus is compared to someone dealing with a homicide. Previously, Aias in the Embassy pleaded unsuccessfully that Achilleus should accept Agamemnon's supplication through an appeal to the circumstances of a hypothetical homicide who was allowed to remain in his community. Here, in the Ransoming of Hektor, Priam's successful supplication is preceded by a simile likening Priam to a fugitive homicide. (Again, we see pointed reversals in the recurrence of a motif.) Moreover, between these two episodes, there intervenes the trial scene on Achilleus' shield (Il. 18.497-500), where the fate of a homicide was seen hanging delicately in the balance. The image of the homicide thus tracks in subtle ways the development of the menis-theme in the Iliadic narrative. ${ }^{39}$ In both the Iliad and the Odyssey, the theme of Achilleus' and Odysseus' anger and revenge against their enemies is significantly linked with comparisons or contrasts with the treatment of a homicide. The evolving image of the homicide is used intratextually in the Iliad to chart the difference between Achilleus in Iliad XXIV and Achilleus in Iliad IX. It is used, arguably, intertextually in Odyssey XXIII to chart the difference (and similarity) between the Odysseus of the Odyssey and the Achilleus of the Iliad.

\footnotetext{
38 'As when intense disaster has gripped a man, who in his own country killed a man and came to another community, to a rich man's house, and wonderment seized them as they looked on; so did Achilleus wonder as he saw Priam, like to the gods.'

${ }^{39}$ Andersen 1976, 14-16.
} 
Without the macrolevel perspective that is opened up by considerations of narratological intertextuality it is rather doubtful whether it would have been possible to interpret the microlevel correspondences between $\mathrm{Od}$. 23.118-22 and $\mathrm{Il}$. 9.632-8 as a meaningful intertextuality. The Odyssean Mnesterophonia and its aftermath (Odyssey books 22-24) may be seen as broadly intertextual with the Iliadic narrative of the Hektoros anairesis and its aftermath (Iliad books 22-24). ${ }^{40}$ But the Odyssey-poet's sensitivity to the bifurcation of the Iliadic narrative makes it meaningful to see this Odyssean narrative (that is, books 2224) as incorporating intertexts from both the Iliadic narrative of Achilleus' anger against Agamemnon and the Iliadic narrative of Achilleus' anger against Hektor. First, Od. 22.61-6 conflates Achilleus' repudiation of compensation from Agamemnon (Il. 9.378-87) and from Hektor (Il. 22.349-54). Second, Od. 23.118-22 employs an image of the fugitive homicide that crucially connects Achilleus' anger against Agamemnon (Il. 9.632-8) with his anger against Hektor (Il. 24.480-2). This image of the fugitive homicide, moreover, illustrates how the poet of the Iliad can first ring the changes intratextually on the theme of vengeance, and how subsequently the Odyssey-poet can do so intertextually.

To summarize the argument of this section: the Iliad's proem implies a simple theme, the menis of Achilleus, which contrary to the first impressions created by its proem turns out to be duplex. The Iliad variously makes play with this duplication of theme: through parallel scenes linking Achilleus' anger with Agamemnon and his anger with Hektor, and through the recurrent and evolving image of the treatment of a homicide. The Odyssey mirrors this: its proem too implies a simple theme, the nostos of Odysseus, which again contrary to first impressions turns out to be duplex. The Odyssey again makes play with this duplication of theme, through parallel scenes linking Odysseus' escape from the sea with his final reunion with Penelope. It is hard, I believe, to see this as an independent development in the Iliad and the Odyssey, especially if we grant the Odyssey's apparently pervasive interest in reading the Iliad's bifurcated menis-theme. It may be recognized rather as a case of narratological intertextuality, of the Odyssey responding to a notable narrative feature of the Iliad.

\section{Fathers}

Another important way in which the Iliad carves out a distinctive narrative from the traditional fabula is in its choice of an end-point. The dramatic climax of Iliad XXIV in the

\footnotetext{
${ }^{40}$ Rutherford 2001 (1991-3), 129-30; Lowe 2000, 150-1; Saïd 2011, 100.
} 
meeting of Achilleus and Priam is, it has been pointed out, an unobvious end-point for a Trojan War epic, compared to, say, Achilleus' death or the sack of Troy. ${ }^{41}$ Something similar may be said of the dramatic climax of Odyssey XXIV in the meeting of Odysseus and Laertes. $^{42}$ It is questionable whether the aged, still-living, Laertes had an established presence in the traditional story of Odysseus' homecoming. ${ }^{43}$ Certainly the motif of Penelope's (un)weaving a shroud for her father-in-law's prospective funeral may not be (very) traditional; it is less obviously motivated than the motif (attested, for instance, in the Life of St Agatha) of a reluctant bride's (un)weaving of a dress for her own prospective wedding. ${ }^{44}$ (Even if - relatively - untraditional, it is not, of course, thereby proven to be an innovation of the Odyssey-poet.) We ought to consider whether, in building up to this emotionally-charged scene between the hero and an old man (his father), the Odyssey contrives to create an unobvious end-point that could be seen as quoting the unobvious endpoint that the Iliad gave to its narrative.

Before assessing the extent to which the Laertes-Odysseus scene of Odyssey XXIV may call to mind the Priam-Achilleus scene of Iliad XXIV, we must first recognize that the Priam-Achilleus scene of Iliad XXIV itself may call to mind (at least) four other scenes. First, the Chryses-Agamemnon scene from the start of the Iliad: another supplication in the Achaean camp by another father, with a very different outcome. Second, an imaginary, counterfactual scene between Peleus and Achilleus: a reunion that never takes place, but is explicitly called to mind (Il. 24.491-2, cf. 23.144-51) and is evoked vicariously by the encounter between Priam and Achilleus. ${ }^{45}$ Third, a scene realized later in the mythological fabula of the Trojan War, featuring Priam and Neoptolemos: Neoptolemos unceremoniously kills Priam, in stark contrast with Achilleus' sympathetic treatment of the aged king (a scene narrated in the Little Iliad fr. 16 Bernabé; Iliou Persis, argumentum Procli p. 88.13-14 Bernabé). ${ }^{46}$ And fourth, a scene realized later on still in the mythological fabula of the Trojan

\footnotetext{
${ }^{41}$ Macleod 1982, 27 and n. 3, citing Bowra 1930, 103-9.

${ }^{42}$ For the reunion with Laertes as a 'dramatic climax' (of book XXIV, not of the poem as a whole), cf. Lowe 2000, 142 '[Laertes'] withdrawal [sc. his removal from the palace situation] ... cleverly locates the zenith of emotion in the reunion with Penelope, with Laertes held in judicious reserve for an epilogue', 154 'the two climactic recognitions', $s c$. of Odysseus with Penelope and Laertes.

${ }^{43}$ M. L. West 2014, 99: 'he may well have been absent from earlier versions'; cf. S. R. West 1989, 115-17. Differently, Danek 1998, 54, speculating about earlier versions in which Laertes may have played a more active part in the plot.

${ }^{44}$ S. R. West 1989, 116.

${ }^{45}$ Il. 24.491-2, cf. 23.144-51.

${ }^{46}$ See esp. Anderson 1997, 44-8. This is on the assumption that Neoptolemos-mythology is well developed before Iliad and Odyssey; differently, M. L. West 2001, 12; 2011, 359. Cf. Virg. Aen. 2.533-55, for Neoptolemos ('Pyrrhus')-Priam, contrasted with Achilleus-Priam; cf. Tryphiodorus 636-9; Q.S. 13.231-5.
} 
War, featuring, this time, Peleus and Neoptolemos: in a rather different contrast with his father, Neoptolemos actually does make it home to meet his grandfather Peleus (a scene narrated in the Nostoi, argumentum Procli p. 95.16 Bernabé) ${ }^{47}$

So, the Priam-Achilleus scene of the Iliad appears to look out towards all sorts of other, powerfully contrastive, scenes. Here two observations are in order. First, it is doubtful whether we can regard these as instances just of a putative traditional motif of 'the father reunited with the returning son', or similar. We are dealing with a sequence of hero-figures (Achilleus-Neoptolemos-Odysseus) and of father-figures (Priam-Peleus-Laertes) who appear to be specifically modelled on one another. It may be left open whether there was any traditional 'father reunited with returning son' motif; but regardless of whether or not there was any such, these episodes should be seen as standing in a specific relationship to one another. $^{48}$

Second, not all of these scenes are to be conceptualized either as narrative or as cases of intertextuality. Neither term (narrative or intertextuality) is applicable to the purely imaginary Peleus-Achilleus scene that is vicariously suggested by the Iliadic Priam-Achilleus scene. The Priam-Neoptolemos scene (which was narrated in the Iliou persis, but not in any comparably closural position) may perhaps best be thought of as being in a form of 'mythological intertextuality' ${ }^{49}$ with the Priam-Achilleus scene. Such mythical intertextuality may perfectly well be conceived as bidirectional; we are at liberty here to think of a reciprocal, non-hierarchical relationship between episodes in the mythological fabula. The same goes for the Peleus-Neoptolemos scene. However, the situation is instructively different with the scenes of Chryses-Agamemnon in Iliad I, Priam-Achilleus in Iliad XXIV, and Laertes-Odysseus in Odyssey XXIV. Here we must think of the scenes precisely as realized in these concrete narrative forms, and must think in terms of, respectively, intratextuality and intertextuality with and between those specific narratives. The intertextuality concerned is, moreover, a hierarchical and unidirectional one. ${ }^{50}$ The Priam-

\footnotetext{
Odysseus at $O d$. 11.506-37 (cf. 507, 517) perhaps glosses over this episode (cf. Anderson 1997, 48; 2011, 569), and Virg. Aen. 2.547-50 perhaps alludes to the omission. Comparably, the Achilleus-Telephos episode is paralleled and inverted in the Neoptolemos-Eurypylos episode, both perhaps already pre-'Homeric' (cf. Od. 11.519-20). For such generational 'cycles' in early Greek epic, see Anderson 1997, 39 n. 19; M. L. West 2006, 16-17.

${ }^{47}$ Cf. Soph. Peleus, Eur. Tro. 1123-8, Eur. Andr., Ps.-Apollod. Epit. 6.12-13; see Gantz 1993, 688-9. Cf. M. L. West 2013, 264; Danek 2015, 369-70.

${ }^{48}$ For the argument here, cf. Currie 2016, 'General Index' s.v. 'type-scene, inadequate to account for given similarities'.

${ }^{49}$ Burgess 2006, 154, 173.

${ }^{50}$ Cf. Currie 2016, General Index s.v. 'allusion, unidrectional'.
} 
Achilleus scene of the Iliad achieves closure in part through its intratextuality with the Chryses-Agamemnon scene at the start of the narrative: the end of the narrative is recognizable as such because it evokes the beginning. The Odyssean Laertes-Odysseus scene in turn arguably achieves closure in part through its intertextuality with the Priam-Achilleus scene at the end of the Iliad: the end of this narrative is recognizable as such because it evokes the end of another narrative, that of the Iliad. ${ }^{51}$ To put this in terms of diachronic narratology's interest in how narrative techniques evolve over time, we may say that an intratextual closural device of ring-composition in the Iliad has been transformed into an intertextual closural device in the Odyssey; and that while the Iliad achieves closure in a selfsufficient way, the closural effect achieved in the Odyssey is essentially parasitic on that achieved in the earlier poem. ${ }^{52}$

The case for intertextuality between the Iliadic Priam-Achilleus and the Odyssean Laertes-Odysseus scenes consists partly in the climactic, closural, positions occupied by each in their respective narratives; but the way the characters are deployed in the narrative is also important. In particular, Peleus in the Iliad is an unseen character. ${ }^{53}$ That is, there are numerous references to him throughout the poem as still living, in Phthia. ${ }^{54}$ These references build up to a palpable climax in book 24, where Peleus' absence assumes real thematic significance. The handling of Laertes in the narrative of the Odyssey is suggestively similar. Throughout the Odyssey there are numerous references to Laertes as still living, but in the country estate (e.g. 1.190) and well out of the purview of the narrative. ${ }^{55}$ Suddenly in the Laertes-Odysseus scene of the final book, he emerges as a flesh-and-blood character in the narrative. ${ }^{56}$ Until book 24 , therefore, Laertes is treated in the Odyssean narrative just as Peleus is treated in the Iliadic narrative, as if he were an unseen character. But the twenty-

\footnotetext{
${ }^{51}$ The authenticity of Odyssey XXIV is here assumed; see, for instance, de Jong 2001, 561-2; Currie 2013; Rutherford 2013, 98-102 (a balanced discussion).

52 The Odyssey has its own ring-composition between the beginning and the end of the story (de Jong 2001, 565; 2004, 18), though much less marked than with the Iliad.

${ }^{53}$ Cf. de Jong 1990, esp. $1 \mathrm{n} .2$ for the term 'off-stage character' (in drama).

${ }^{54}$ Il. 7.125; 9.252, 394, 400, 438, 480; 11.772, 783; 16.15, 18.331, 19.334-7, 22.420-2, 23.144-51, 24.486-92, 24.538-42. Polinskaya 2011, 638 'The Iliad is full of reminiscences of Peleus.'

${ }^{55}$ Cf. Od. 1.188-93, 2.96-102, 4.111, 4.735-41, 11.187-96, 14.173, 15.353-7, 16.137-53, 16.302, 22.184-6.

${ }^{56}$ De Jong 2001, 27 '[the narratees] are periodically reminded of [Laertes]', 574 'After numerous references to Laertes, this character is finally allowed to enter the stage.' Cf. Lowe 2000, 152 'Laertes' circumstances are outlined at $[O d .1] 188-$.93 , but in terms indicating he will not be a critical component of the endgame'; 153 'again [sc. at $O d .11 .187-96$ ] a promise of a Laertes scene, but of what kind and in what context is still teasingly opaque.' Differently, Danek 1998, 54 supposes that there may have been versions in which Laertes was drawn into the action before the killing of the suitors, and that a listener familiar with such versions would find crossreferences to them in these mentions of Laertes.
} 
fourth book offers a striking departure from the Iliadic model. ${ }^{57}$ The effect might again be characterized as another example of intensification: the climactic Odyssean scene trumps the climactic Iliadic scene, as Odysseus really is reunited with his father, and as Laertes débuts late in the narrative as a real character, no longer an unseen one.

There is another reason to see the Laertes of Odyssey XXIV as modelled allusively on the Peleus of Iliad XXIV. The Odyssey-poet seems to have had the Peleus of Iliad XXIV in mind at $O d$. 11.494-503, where Achilleus' shade speculates about Peleus' state in his absence. These verses seem specifically to recall $\mathrm{Il}$. 24.488-92, where Priam speculated about Peleus's state in Achilleus' absence. ${ }^{58}$ Moreover, Antikleia's shade described to Odysseus Laertes' state in Odysseus' absence in similar terms a little earlier in the Nekyia (Od. 11.187-96). The equivalence of Laertes and Peleus that is exploited in the twenty-fourth book thus appears to be carefully prepared already in the eleventh.

There are additional reasons to recognize intertextuality between the LaertesOdysseus scene in Odyssey XXIV and the Priam-Achilleus scene in Iliad XXIV. The last book of the Iliad is generally recognized to be one of the most significant Iliadic intertexts for the Odyssey. ${ }^{59}$ The council of the gods at the beginning of Odyssey I, in which 'all the gods' (except Poseidon: Od. 1.19-20) pity the absent Odysseus arguably recalls the council of the gods at the beginning of Iliad XXIV, in which 'all the other gods' (except Hera, Poseidon, and Athena: Il. 24.25-6) pitied the dead Hektor; subsequently, the dispatch of Athena to Telemachos and of Hermes to Kalypso in Odyssey I and V arguably recalls the dispatch of Iris to Thetis and of Hermes to Priam in Iliad XXIV. ${ }^{60}$ We would accordingly have intertextual engagement with Iliad XXIV bookending the Odyssey in books 1 and 24. But, perhaps, not just bookending it: I have argued elsewhere that the narrative in Iliad XXIV of Priam's journey to Achilleus' tent and his sudden supplication of Achilleus at dinner is recalled in Odysseus' journey to Alkinoos' palace and his abrupt supplication of Arete-

\footnotetext{
${ }^{57}$ S. R. West $1989,115-18$, disputing the authenticity of the $24^{\text {th }}$ book, argued that all these references to Laertes were interpolations. There is, admittedly, a certain artificiality to them, but it is much preferable to see them as carefully controlled authorial interventions in the narrative than as interpolations. Precisely the parallel with the Iliadic Peleus constitutes a further argument in favour of their authenticity.

${ }^{58}$ Macleod 1982, 128; Rutherford 2001 (1991-1993), 134. It is notable that the years that have elapsed in the fabula between Il. 24.488-92 and $O d$. 11.494-503 have made no difference to the way in which we visualize Peleus: he is still old, alive, and vulnerable, and Achilleus still repines his failure to help him (Od. 11.498, cf. Il. 24.540-1); this, in other words, is still very much the Peleus of Iliad XXIV. Differently, Danek 1998, 240-1.

${ }^{59}$ Cf. Hölscher 1988, 80-1; Usener 1990, 204; Rutherford 2001 (1991-3), 131-2; N. J. Richardson 1993, 22-3; M. L. West 2014, 70, 76.

${ }^{60}$ Usener 1990, 165-79; Rutherford 2001 (1991-3), 131; N. J. Richardson 1993, 22-3.
} 
Alkinoos at dinner in Odyssey VI-VII. ${ }^{61}$ If so, we would have successive parts of the Odyssey (I, VI-VII and XXIV) engaging with successive parts of the narrative of Iliad XXIV. Throughout this sequence we would see Odysseus being linked with, first (in Odyssey I), Hektor, as the dead / 'departed' family member requiring to be returned to his family; second (in Odyssey VI-VII), Priam, as the suppliant desperate to secure the return of the dead or 'departed' family member (i.e. himself!) to his family; ${ }^{62}$ and third (in Odyssey XXIV), Achilleus, as the son separated from his father. In a significant set of contrasts, then, Odysseus' position would be favourably compared with that of multiple Iliadic figures. (Favourably, because Odysseus, unlike Hektor, is not dead; because Odysseus' supplication of the Phaeacians, unlike Priam's of Achilleus, results in his receiving rather than his giving gifts; and because Odysseus, unlike Achilleus, is actually reunited with his father.) These differences would highlight key differences in the Odyssean and Iliadic conceptions of their hero, in respect of their attitudes to personal survival, to material possessions, and to the family. ${ }^{63}$

\section{$V$ The interlace technique}

The interlace technique, or interweaving of discrete storylines, has been seen as a speciality of the Odyssey. ${ }^{64}$ A. Rengakos, following U. Hölscher, has argued, however, that the technique is modelled on an analogous technique found in the Iliad. ${ }^{65}$ The adoption of the technique would then appear to associate the Odyssey strongly with the Iliad, and just as strongly to dissociate both of these poems from the Epic Cycle, which notoriously had limpidly sequential (linear) plots. ${ }^{66}$ That aspect, at least, is persistently emphasized in the ancient reception of the Cycle. We encounter it, firstly, in Virgil's phrase Iliacas ex ordine pugnas / bellaque iam fama totum uulgata per orbem (Aeneid 1.456-7: ecphrasis of the

\footnotetext{
${ }^{61}$ Currie 2016, 42-5. Differently, Danek 2016, esp. 125-32.

62 The verb oílopol used of Odysseus (Od. 4.166, 19.266) can suggest 'dead' as well as 'departed': cf., in general, Garvie 2009, 50.

${ }^{63}$ Cf. Rengakos 2002, 185-6; Saïd 2011, 375-7.

${ }^{64}$ De Jong 2001, 589-90; 2002, 77-8; Rengakos 2002, 175-6; cf. Saïd 2011, 96-100. This is apparently not what Aristotle meant at Poet. 1459b14-15: see de Jong 2002, 78 (pace Saïd 2011, 100).

${ }^{65}$ Hölscher 1988, 85-6. Rengakos 2002, 174-5; 2015, 156-7. Cf. Hellwig 1964, 22 'Die Handlung ist in verschiedene Stränge gegliedert. Wie ein "Kampf um Troja" hätte auch eine "Heimkehr des Odysseus"

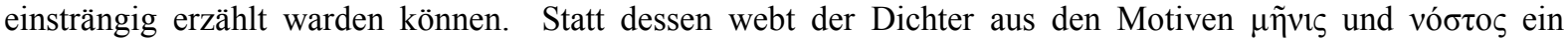
mehrstängiges Gewebe, in dem entgegegesetzte Willens- und Wissensrichtungen die maßgebenden Kräfte sind.' ${ }^{66}$ Rengakos 2015, 157.
} 
murals on Juno's temple in Carthage). ${ }^{67}$ Secondly, in the Imperial-age epigrammatist

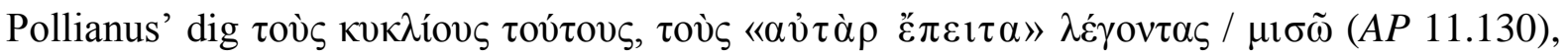
with the unflattering implication that a pedestrian concatenation of events was typical of the

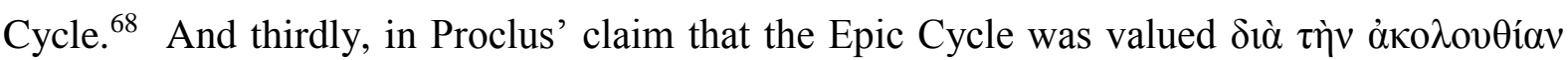

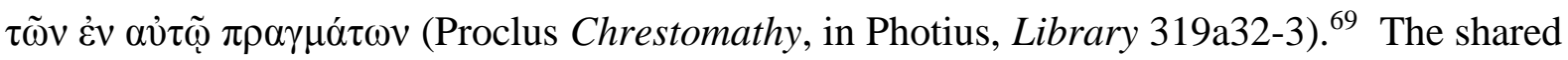
use of an interlace technique deserves therefore to be investigated as another possible instance of narratological intertextuality between the Iliad and Odyssey.

An immediate difficulty arises with the question of how to identify storylines. Rengakos sees two interwoven storylines in each poem: in the Iliad, a Patroklos storyline (which he also refers to as an Achilles plot-line) and an actual fighting storyline; ${ }^{70}$ in the Odyssey, a Telemachos storyline and an Odysseus storyline. De Jong identified not two, but three interlaced storylines in the Odyssey: an Odysseus storyline, a Telemachos storyline (so far, as Rengakos), and an additional Ithaca storyline. ${ }^{71}$ B. Hellwig distinguished three storylines in the Iliad: an Achilleus storyline, a battle storyline (compare, thus far, Rengakos), and a gods storyline. And she distinguished four in the Odyssey: an Odysseus storyline, a Telemachos storyline (so far, as Rengakos), a Suitors storyline and a Penelope storyline (similarly, de Jong, whose Ithaca storyline, however, subsumes the two last). ${ }^{72}$ It appears that there is considerable subjectivity in what gets counted as a storyline, in either poem. It will not ameliorate that impression of subjectivity that I am going to propose a three-storyline analysis for each poem which differs from, but also has much in common with, the preceding analyses (see Tables 1 and 2). De Jong's conception of the storylines of the Odyssey forms the backbone of this analysis. I have taken over her analysis of storylines of the Odyssey with only superficial modification, ${ }^{73}$ and have endeavoured to map a similar conception of storylines onto the Iliad in order precisely to maximize comparability between the two poems. These analyses need not be considered definitive; in fact, I believe it is sufficient for our purposes simply if there is some such approximate analysis that makes the point. It is true that an argument for meaningful narratological intertextuality requires that poet(s) and audience perceived the storylines in a particular way; but we need not suppose that they

67 'Trojan battles in succession, wars that have now been made common knowledge by their reputation over the whole world' - or 'through the entire Cycle': see Barchiesi 1999, 333-4; Fantuzzi 2015, 422-4.

68 'I detest those Cyclical poets, the ones who say "and then"'.

69 'Because of the sequentiality of the events in it.' See Fantuzzi 2015, 408-9.

${ }^{70}$ Cf. Hellwig 1964, 127, and passim, distinguishing an 'Achillhandlung' and a 'Kampfhandlung' (though Hellwig also allows for a 'Götterhandlung').

${ }^{71}$ De Jong 2001, 589.

${ }^{72}$ Hellwig 1964, 10-13, 20.

${ }^{73}$ I have re-termed de Jong's 'Ithacan storyline' an 'Odysseus' family versus Suitors storyline'. 
perceived them in exactly the way proposed: it is enough for the argument for narratological intertextuality that they perceived each poem as employing interlaced storylines in significantly comparable ways, for instance, along roughly the lines suggested here. 
Table 1: Main storylines and interlace technique in the Iliad

\begin{tabular}{|c|c|c|}
\hline Achilleus storyline & Patroklos storyline & $\begin{array}{l}\text { Achaeans versus Trojans } \\
\text { storyline }\end{array}$ \\
\hline \multicolumn{3}{|c|}{ (Achaeans versus Trojans storyline) } \\
\hline \multicolumn{3}{|c|}{$1.1-348 \mathrm{a}$} \\
\hline \multicolumn{2}{|c|}{$\begin{array}{l}\text { (Achilleus storyline splits off from Achaeans versus Trojans } \\
\text { storyline) }\end{array}$} & \\
\hline \multicolumn{2}{|c|}{$1.348 b-430 a$} & \\
\hline & & $1.430 \mathrm{~b}-487$ \\
\hline \multicolumn{2}{|c|}{$1.488-610$} & \\
\hline & & $2.1-9.181$ \\
\hline \multicolumn{2}{|c|}{$9.182-668$} & \\
\hline & & $9.669-11.598$ \\
\hline \multicolumn{2}{|c|}{$11.599-615$} & \\
\hline & \multicolumn{2}{|l|}{$\begin{array}{l}\text { (Patroklos storyline splits } \\
\text { off from Achilleus storyline) } \\
11.616-848\end{array}$} \\
\hline & & $12.1-15-15.746$ \\
\hline \multicolumn{2}{|c|}{ (Patroklos storyline re-merges with Achilleus storyline) } & \\
\hline & \multicolumn{2}{|c|}{$\begin{array}{c}\text { (Patroklos storyline splits off again from Achilleus } \\
\text { storyline, merges with Achaeans vs Trojans storyline) } \\
16.257-17.761\end{array}$} \\
\hline \multicolumn{3}{|c|}{$18.1-148 \mathrm{a}$} \\
\hline & & $18.148 b-164$ \\
\hline \multicolumn{2}{|c|}{$18.165-231 \mathrm{a}$} & \\
\hline \multicolumn{3}{|c|}{ (All three storylines merged) } \\
\hline \multicolumn{3}{|c|}{$18.231 b-24.804$} \\
\hline
\end{tabular}


Table 2: Main storylines and interlace technique in the Odyssey (after de Jong 2001: 589-90)

\begin{tabular}{|c|c|c|}
\hline Odysseus storyline & Telemachos storyline & $\begin{array}{c}\text { Odysseus' family versus } \\
\text { Suitors storyline }\end{array}$ \\
\hline \multicolumn{3}{|l|}{$1.1-95$} \\
\hline & \multicolumn{2}{|c|}{$1.96-2.434$} \\
\hline & $\begin{array}{l}\text { (Telemachos storyline splits } \\
\text { off from Odysseus' family } \\
\text { storyline) } \\
\text { 3.1-4.624 }\end{array}$ & \\
\hline & & $4.625-847$ \\
\hline \multicolumn{3}{|l|}{$5.1-14.533$} \\
\hline & $15.1-300$ & \\
\hline \multicolumn{3}{|l|}{$15.301-495$} \\
\hline & $15.495-557$ & \\
\hline \multicolumn{3}{|c|}{$16.1-321$} \\
\hline & & $16.322-451$ \\
\hline \multicolumn{2}{|c|}{$16.452-481$} & \\
\hline \multicolumn{3}{|c|}{ (All three storylines merged) } \\
\hline & $17.1-24.519$ & \\
\hline
\end{tabular}


Something must be said by way of clarification of the above analyses. As indicated earlier, the definition of storyline is itself unclear. ${ }^{74}$ I take it that, strictly, we must recognize that we have a storyline whenever the narrative concerns itself with the narration of the experiences of one character (or group of characters) and the narration of the experiences of one or more other characters (or groups of characters) is held in abeyance while it does so. It follows that both the Iliad and Odyssey contain a plethora of storylines. Of these, we must restrict ourselves to the main ones: those that have significant duration and have significant consequences for the narrative. The subjectivity that we have already noted in the identification of storylines thus resolves itself into the difficulties of determining what constitutes a main storyline and what descriptive label to attach to it. I have defined the storylines with reference to the characters who are their main thematic focus: thus, in the Iliad, Achilleus, Patroklos, the Achaeans and the Trojans; in the Odyssey, Odysseus, Telemachos, Odysseus' family and the Suitors (the last departing from de Jong's spatiallyconceived Ithacan storyline). I have treated storylines involving just the Trojans in the Iliad (such as Hektor in Troy in book 6) or just the Suitors in the Odyssey as subsidiary storylines to the main storylines of Achaeans versus Trojans and Odysseus' family versus Suitors respectively. I have taken a similar approach to divine scenes, which can often be regarded as subsidiary to main storylines focussed on a human character (or characters). ${ }^{75}$ Hence, with de Jong, I treat $O d$. 1.1-95 as subsidiary to an Odysseus storyline, even though the scene is Olympus; likewise the first Olympian scene of the Iliad can be regarded as subsidiary to an Achilleus storyline (indeed, the lead-in to that divine scene, $I l$. 1.488-97, encourages this). It follows in general that changes of scene (for instance, from the Trojan plain to the city of Troy in the Iliad, from the $\mu \varepsilon \dot{\gamma} \alpha \rho \mathrm{v}$ to the $\dot{\tau} \varepsilon \varepsilon \rho \tilde{\omega} \mathrm{ov}$ in the Odyssey, or from the earth to Olympus in both poems) will commonly occur with transitions between subsidiary storylines within a single main storyline.

As previously stated, I have identified the storylines in my analysis in such a way as to optimize the prospects of finding a narratological intertextuality between the Iliad and Odyssey; let us see now what that amounts to. The far right-hand columns of each table (Achaeans versus Trojans and Odysseus' family versus Suitors) represent the story of each poem in its most basic form. In the far left-hand columns we have a storyline focussed on the

\footnotetext{
${ }^{74}$ For one definition, cf. Hellwig 1964, 129 'Es konstituiert einen Handlungstrang, daß er gesondert von anderen Vorgängen verläuft und dadurch als eigene Linie klar erkennbar ist.'

75 Differently, Hellwig 1964, 12-13, 21 'Auch die Götter warden betroffen: sie sind so stark in das Geschehen einbezogen, daß sie eine eigene Handlungslinie haben.'
} 
main hero (Achilleus, Odysseus), which becomes temporarily separated out from this (resulting in a retardation of the story) and ultimately subsumed in it (enabling the story to proceed towards a conclusion). The middle column (Patroklos, Telemachos) represents a storyline that is a doublet of the hero's story. Thus the Patrokleia (Iliad XVI-XVII) replicates, in a kind of mise en abyme, the Achilleus-fabula in miniature: the death of Patroklos evokes the death of Achilleus. The Telemachy (Odyssey III-IV) likewise mirrors the Odyssey in miniature: Telemachos' wanderings and personal danger evoke those of Odysseus (see especially $O d$. 13.418-19). ${ }^{76}$ A notable difference is that the Patroklos storyline has an instrumental role in bringing about a reintegration of the Achilleus storyline with the Achaeans storyline; the Telemachos storyline lacks any comparable instrumental role, as Telemachos goes only in search of news of his father $(O d .1 .93-5,1.279-81,13.415)$. It is possible, however, that in earlier tellings of the Homecoming of Odysseus Telemachos did indeed have an instrumental role in bringing Odysseus back to Ithaca (presumably, from Crete), and the Odyssey has been argued both to suppress and to allude to such traditions; ${ }^{77}$ additional awareness of a narratological intertextuality with the Iliad would reinforce the audience's sense that the Telemachos storyline within the Odyssey has indeed been stripped of such an instrumental role. There are other noteworthy parallels between the Patroklos and Telemachos storylines. Thus, after the Patroklos storyline splits off to become a third discrete storyline in Iliad XI, Patroklos goes first to Nestor and then to Eurypylos, with whom he tarries for several books of narrative time (books 12-15); after the Telemachos storyline splits off to become a third discrete storyline in Odyssey III, Telemachos goes first to Nestor (is this a purely fortuitous coincidence?) and then to Menelaos, with whom he tarries for several books of narrative time (books 4-15). Further, the final remerging of the storylines in the Iliad is brought about by Patroklos' death at the hands of the Trojans, and the recovery of his body by the Achaeans and then by Achilleus; the final remerging of the storylines in the Odyssey is brought about by Telemachos' narrow escape from death at the hands of the Suitors, and his restoration to Odysseus and then to Penelope: in evading death Telemachos, therefore, could be said to defy not just the Suitors' plans, but also our own intertextual expectations. Finally, we should emphasize the basic fact of the orchestration of the various storylines itself: the juggling of two or three storylines from early on in the poem, the merging of the storyline shown in the middle column of the tables in turn with each of the storylines on either side of it, and the final subsuming of all the storylines into a single

\footnotetext{
${ }^{76}$ Currie 2016, 128 and n. 132.

${ }^{77}$ Cf. Reece 1994; Danek 1998, 47-9; Steiner 2010, 84-5; Tsagalis 2012, 318-19
} 
storyline for approximately the last third of the poem. Does any or all of this add up to a plausible case for narratological intertextuality? We must, of course, remember that these storylines have been drawn up with the express purpose of facilitating the argument for a narratological intertextuality; but even so it seems hard to attribute all the similarities that are observable here to either coincidence or the bare workings of tradition. Whether in this case we are to think of allusion or of the same poet working unconsciously in similar ways (if we are prepared to entertain common authorship of both poems) could of course be debated.

The table of contents ${ }^{78}$ speeches, delivered by either Athena or Zeus in both Iliad and Odyssey, could be argued to advertise explicitly the narrator's orchestration of the interlaced storylines. ${ }^{79}$ These declarations of the deity's intentions, read metapoetically, will serve to thematize the poet's manipulation of the various storylines. Thus, in the Iliad, Athena at 1.212-14 can be seen to intimate the fragmentation of an Achilleus storyline from the Achaeans versus Trojans storyline (assuming that her foretelling of the recompense to be offered to Achilleus presupposes his antecedent withdrawal). Zeus at 8.470-7 anticipates the merging of the Achilleus storyline with the Achaeans versus Trojans storyline after the death of Patroklos. Zeus again at 15.59-71 (the fullest such speech) presupposes, first, an Achaeans versus Trojans storyline, as separate from an Achilleus storyline (lines 59-64); second, the merging of a Patroklos storyline with the Achaeans versus Trojans storyline (lines 64-67); and third, the merging of an Achilleus storyline with the Achaeans versus Trojans storyline (lines 68-71). In the Odyssey, Athena at 1.82-95 adverts to separate Odysseus and Telemachos versus Suitors storylines. ${ }^{80}$ Zeus at 5.30-42 references the Odysseus storyline, and intimates its ultimate merging with an Odysseus' family storyline. Athena at 13.411-15 undertakes the reintegration of Odysseus and Telemachos storylines. Such divine speeches offer some reassurance, I submit, that the analysis of the narrative into the storylines proposed here (viz., in the Iliad: an Achaeans versus Trojans, an Achilleus, and a Patroklos storyline; in the Odyssey: an Odysseus' family, an Odysseus, and a Telemachos storyline) is not completely arbitrary and corresponds at least broadly to the way the poet(s) were conscious of conceiving them.

\footnotetext{
${ }^{78}$ De Jong 2001, 15. Cf. M. L. West 2014, 58.

${ }^{79} \mathrm{Cf}$. in general S. Richardson 1990, 191-5.

${ }^{80}$ Cf. de Jong 2001, 16 'Athena's speech introduces a new storyline: from now on there is an "Odysseus" storyline and a "Telemachus-Ithaca” storyline.'
} 
In addition to their shared adoption of the interlace technique, both the Iliad and Odyssey observe a continuity of time principle. ${ }^{81}$ This principle entails that the clock ticks in the same way in each storyline (i.e. the clock is put neither back nor forward when transitioning between storylines), but that by convention nothing of importance happens in any storyline other than the one currently being narrated. ${ }^{82}$ Nonetheless, the storylines are understood to be constantly running in parallel with one another. ${ }^{83}$ The consistent observance of this principle should be recognized as a deliberate poetic choice. ${ }^{84}$ There were alternative ways available of co-ordinating storylines. M. Fludernik, surveying a wide range of literary works in English, distinguishes 'scene shifts' in which 'time remains the same but scene changes' (this, essentially, is our 'continuity of time') or 'time changes and scene changes' or 'time changes but scene (and character) remain the same. ${ }^{95}$ The continuity of time principle appears not to have held sway in the Cypria (the Cyclical epic that is least poorly documented for us). In that poem, after the narration of Helen's elopement with Paris, the clock appears to have been put back for a narration of the conflict of the Dioskouroi with the Apharetidai -

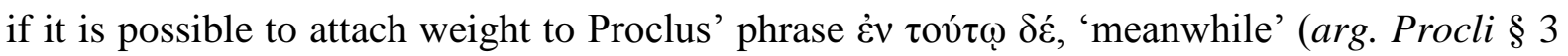

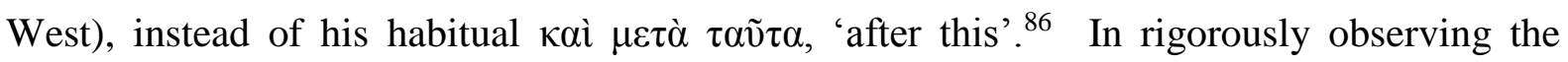
continuity of time principle, therefore, the poet of the Odyssey could arguably be seen as composing in a pointedly Iliadic vein. Conversely, it has been argued that the poet of the Doloneia, in persistently departing from the continuity of time principle, was just as pointedly composing in an un-Iliadic vein. ${ }^{87}$

\footnotetext{
${ }^{81}$ Also known as 'Zielinski's law', on which see e.g. S. Richardson 1990, 90-5; de Jong 2007, 30-1; Scodel 2008.

${ }^{82}$ Cf. Hellwig 1964, 59.

${ }^{83}$ Contemporaneity of the Patroklos storyline and the Achaeans vs Trojans storyline: Il. 12.1-3, 15.390-7 (see de Jong 2007, 30; Scodel 2008, 110); cf. 11.596-8. Contemporaneity of the Telemachos storyline and the Odysseus' family vs Suitors storyline: Od. 4.624-5 (see Saïd 2011, 98, 109).

${ }^{84}$ Danek 2012, 111 'When we take a look at the South Slavic epic tradition, we realize that individual singers within a single tradition may handle similar restrictions of time management quite differently. So we may conclude that Homer's [consistent] adherence to "Zielinski's Law" was his deliberate choice to economize [sic] his narrative requirements.' The 'law', however, was not rigidly applied in Homer: Scodel 2008.

${ }^{85}$ Fludernik 2003, 334-44.

${ }^{86}$ It is, however, possible that this 'meanwhile' is the epitomizer's (Proclus') interpretation of the narrative, as involving 'disguised simultaneity' rather than 'real sequence' (see Nünlist 2009, 80 n. 28 for the terms, and cf. Scodel 2008, passim). On 'discontinuity of time' in the Cypria, see further M. L. West 2013, 62-3.

${ }^{87}$ Danek 2012, 111-16 esp. 116 'the Doloneia poet not only systematically violates "Zielinski's Law", but demonstrates that he does so deliberately. He differs from the Iliad poet's style not for lack of poetic mastery, but because he wants to do so.' There may have been interlacing in the Nostoi, in imitation of the Odyssey: Danek 2015, 372-5; cf. Rengakos 2015, 162.
} 
Something, finally, needs to be said about the manner of moving between the main storylines. ${ }^{88}$ In the Iliad, where the geographical sphere of action is restricted, transitions between the storylines are relatively easily effected; often we just follow characters physically from one storyline into another. ${ }^{89}$ Sometimes transitions, especially in sections where they fall frequently (Il. 1.348, 430, 488-9; cf. 18.148), are made simply with av่ ó $\rho$ plus a personal name, but even these are hardly experienced as jarring. In the Odyssey it is somewhat different. ${ }^{90}$ In some cases again we simply follow characters into a different storyline. ${ }^{91}$ At other times we get creatively associative transitions. Thus, at $O d$. 4.620-6, we move from the company of feasters in Sparta to the company of Suitors on Ithaca. ${ }^{92}$ At $\mathrm{Od}$. 14.523-15.8, we move from Odysseus and Eumaios in the swineherd's steading, sleeping and not sleeping respectively, to Peisistratos and Telemachos in Sparta, simultaneously sleeping and not sleeping respectively. ${ }^{93}$ The transition to the Odysseus storyline at $O d .5 .1 \mathrm{ff}$. is managed by staging another divine council almost identical to the one at $1.26 \mathrm{ff}$. which had previously launched the Odysseus' family versus Suitors storyline and the Telemachos storyline. $^{94}$ At $O d .15 .301$ and 495 we get unapologetically bald transitions from the Telemachos storyline to the Odysseus storyline and vice-versa. ${ }^{95}$ In general, it is fair to say the Odyssey is more adventurous in its negotiation of the storylines, presenting more drastic scene changes (the Iliad's three main storylines are all set on the Trojan plain; the Odyssey's for the most part in three different geographical spheres: Ithaca, the Peloponnese - PylosSparta - and the fantasy world: Ogygia-Scheria). Furthermore, as de Jong puts it, '[w]hereas in the Iliad the narrator usually drops a storyline when it has reached a situation of rest, in the

\footnotetext{
${ }^{88}$ In general on moving between scenes in Homer (which is not synonymous with moving between the main storylines), see e.g. S. Richardson 1990, 110-19.

${ }^{89}$ As is the usual practice with moving between scenes: Odysseus, Phoinix, and Aias go from the Achaean camp to Achilleus' tent in Il. 9.181; they return from Achilleus' tent to the Achaean camp in 9.669. Patroklos goes from Achilleus' tent to the Achaean camp in 11.616; he returns to Achilleus' tent from the Achaean camp in 16.1; and he goes into battle for the Achaeans from Achilleus' tent in 16.257.

${ }^{90}$ Hellwig 1964, 129 'Zwischen den Figuren, die sich auf räumlich weit getrennten Schauplätzen befinden, entstehen keine direkten Beziehungen, wie z. B. Wahrnehmungen oder Botengänge. Nur die Zeit verbindet sie insofern, als die Ereignisse einander zeitlich genau folgen, was zuweilen pointiert hervorgehoben ist. Im übrigen vollzieht allein der Erzähler den Blickwechsel.'

${ }^{91}$ Athena goes to Sparta at $O d .15 .1-2$ (but see also n. 92 below); Telemachos goes to Eumaios' hut at 15.555-7; messengers and Eumaios go with news of Telemachos' return to Penelope at 16.322ff.; Eumaios returns from palace to his own hut at 16.452ff.; Telemachos at 17.1ff. and Odysseus at 17.182ff. go from Eumaios' hut to the palace.

${ }_{92}$ De Jong 2001, 113; Saïd 2011, 98, 109; M. L. West 2014, 61.

${ }^{93}$ M. L. West 2014, 61. The transition is facilitated by Athena's travelling to Sparta (15.1-2: see n. 90 above); but she absented herself from the 'Odysseus storyline' much earlier (13.439-40).

${ }^{94}$ See, for instance, de Jong 2001, 123-4; 2007, 30-1; Scodel 2008, 115.

${ }^{95}$ De Jong 2001, 374 'The change of scene is abrupt', 381 'The change of scene, from Eumaeus' hut to Telemachus, lacks correspondence, but is prepared for by the narrator in the form of an appositive summary'.
} 
Odyssey it is not seldom in an open, unresolved state. ${ }^{96}$ Here, therefore, even in this most minimal form of diachronic narratology, we seem to be able to trace the development of a narrative technique from the Iliad to the Odyssey. ${ }^{97}$

\section{Conclusions}

The narratological perspective can provide a wealth of supporting arguments in favour of there being a productively intertextual relationship between the Iliad and the Odyssey. Conversely, diachronic and intertextual perspectives are capable of enriching narratological approaches to the Homeric poems in various ways. To indicate one: such (allusive) intertextuality implies the poet's or poets' own self-awareness about certain narratological or narrative features in the texts, viz. the in medias res approach, the tacit bifurcation of the poem's theme, the production of closure, the interlace technique. The poets themselves (and not just their ancient critics) ${ }^{98}$ are thereby shown to be responsive to certain narratological aspects of the texts. It follows that the techniques that are the object of modern narratological study are not just the indispensable, enabling, scaffold of story-telling, whether oral or written, ${ }^{99}$ but something that the poets could consciously fix on - without, of course, their either having or requiring an elaborate jargon for it.

Further, we cannot think of narratology just as the study of a repertory of quasitranscendental techniques to which any narrating author more or less inevitably recurs. The poet of the Odyssey must be understood on several occasions to recur not to any such quasitranscendental repertory, but to the narratological techniques specifically deployed in the Iliad. These techniques are deployed allusively in the Odyssey in the sense that they plainly presuppose the way that they were used in the Iliad. The Priam-Achilleus father-son scene in the Iliad has closural force because it is in ring-composition with the Chryses-Agamemnon father-son scene; but the father-son scene Laertes-Odysseus has closural force because it is intertextual with the Priam-Achilleus scene at the end of the Iliad. The use of Laertes as a

\footnotetext{
${ }^{96}$ De Jong 2001, 590.

${ }^{97}$ Hellwig 1964, 124-5 'Gegenüber der Ilias ist die Schilderung langdauernde Parallelhandlungen neu. Der Dichter erprobt Möglichkeiten, die in dem älteren Werk erst angedeutet sind', 130 'Dabei ist eine gewisse Entwicklung der Gestaltungsweise von der Ilias zur Odyssee zu bemerken, insofern die erzähltechnischen Mittel, die in der Ilias andeutungshaft erscheinen, in der Odyssee bis zu artifizieller Beherrschung weitergebildet sind.'

${ }^{98}$ Compare Aristotle and Horace, cited above, on the in medias res approach; and see in general Nünlist 2009, passim for the narratological concerns of ancient scholarship.

${ }^{99}$ On the applicability of narratology to oral (Homeric) poetry, cf. de Jong 1991.
} 
nearly-unseen character (or unseen character manqué) in the narrative of the Odyssey depends on the use of Peleus as an unseen character in the narrative of the Iliad. The Odyssey's use of the interlace technique exhibits a confidence or boldness that stems from its being an extension of the use of the technique in the Iliad. These developments may be interpreted as instances of Odyssey building on or going further than the Iliad. Iliadic narrative techniques (specifically, closural ring-composition, the unseen character, interlaced storylines) can therefore be as much the object of allusion in the Odyssey as Iliadic themes, scenes, or phrases.

It is also a virtue of the diachronic narratological approach to emphasize that narrative techniques are not just static. Not only can we see evolution (and allusion) in the way techniques are deployed, but in some cases the techniques themselves are revealed to be rather fluid and amorphous. In the Argonautica, Herakles starts out as a flesh-and-blood character, but becomes something like an unseen character from book 2 onwards. ${ }^{100}$ This reverses the development we have seen with Laertes in Odyssey, who had appeared to be an unseen character from book 1 until before becoming a flesh-and-blood one in book 24 . It is, however, exceedingly doubtful whether we should see this as a form of (allusive) narratological intertextuality. Apart from anything else, there is no apparent reason to link Apollonius' Herakles with the Peleus of the Iliad or the Laertes of the Odyssey. By contrast, there is good reason to link the Odyssean Laertes with the Iliadic Peleus. Accordingly, we should say that the Argonautica does not allude or reprise a technique found in either Iliad or Odyssey, but that it employs the same (?) technique independently, and contrastingly. But what, then, is the technique, exactly? We have moved from the concept of the unseen character to that of the nearly unseen character (with rather different inflections). In the Aeneid (a poem admittedly not in Greek, but still very much in the tradition of Greek epic), Lavinia is a character not so much unseen as unheard; or, to apply the tragic model that Virgil quite possibly has in mind, she is not so much an off-stage character (to use de Jong's term) as a kophon prosōpon. All these devices of revealing character within a narrative may be typologically related, and it would seem to make some sense to compare them; but not all can be subsumed under the rubric of the (nearly) unseen character. A technique may not only evolve, or mutate, it may also cross-pollinate. With the Iliad and the Odyssey we have diachronic narratology in a maximally controlled form, where, notwithstanding the oral background of the poems, the case for narratological intertextuality (that is, the specific,

${ }^{100}$ Cf. Köhnken 2014, 141. See also Bär, this volume. 
allusive, reprising of narrative devices) is at its most favourable. It follows that the story told by a diachronic narratology of Greek epic may fall out quite differently according to whether we survey a whole tradition or just a small segment of it: there is, accordingly, I submit, a place for the myopic view of the diachronic narratology of ancient Greek epic that is taken in this paper as well as for the panoramic view which is taken by others in this collection. 
References

Andersen, Ø. 1976. "Some Thoughts on the Shield of Achilles.” SO 51: 5-18.

Andersen, Ø. and Haug, D. T. T., eds. 2012. Relative Chronology in Early Greek Epic Poetry. Cambridge.

Anderson, M. J. 1997. The Fall of Troy in Early Greek Poetry and Art. Oxford.

Barchiesi, A. 1999. "Representations of Suffering and Interpretation in the Aeneid." In Virgil: Critical Assessments of Classical Authors, edited by P. Hardie, vol. 3: 324-44. London and New York.

Bowra, C. M. 1930. Tradition and Design in the Iliad. Oxford.

Burgess, J. S. 2006. "Neoanalysis, Orality, and Intertextuality: An Examination of Homeric Motif Transference". Oral Tradition 21 (1): 148-89.

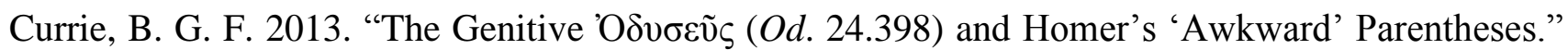
JHS 133: 21-42.

Currie, B. G. F. 2016. Homer's Allusive Art. Oxford.

Danek, G. 1998. Epos und Zitat. Studien zu den Quellen der Odyssee. Vienna.

Danek, G. 2012. “The Doloneia Revisited.” In Andersen and Haug, eds., 106-21.

Danek, G. 2015. “Nostoi.” In Fantuzzi and Tsagalis, eds., 355-79.

Danek, G. 2016. "Modes of Intertextuality in Homer and Bosnian Epic.” In Omero: Quaestiones disputatae, edited by F. Gallo, 123-45. Milan.

Fantuzzi, M. 2015. "The Aesthetics of Sequentiality and its Discontents.” In Fantuzzi and Tsagalis, eds., 405-29.

Fantuzzi, M. and Tsagalis, C., eds. 2015. The Cambridge Companion to the Epic Cycle. Cambridge. 
Fludernik, M. 2003. “The Diachronization of Narratology.” Narrative 11: 331-48.

Gantz, T. 1993. Early Greek Myth: A Guide to Literary and Artistic Sources. Baltimore and London.

Garvie, A. F. 2009. Aeschylus Persae. Oxford.

Griffin, J. 1995. Homer: Iliad IX. Oxford.

Hellwig, B. 1964. Raum und Zeit im homerischen Epos. Hildesheim.

Hölscher, U. 1988. Die Odyssee: Epos zwischen Märchen und Roman. Munich.

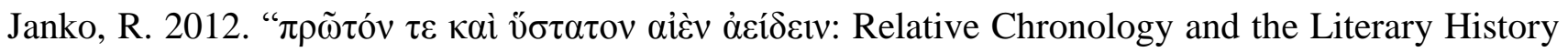
of the Early Greek Epos.” In Andersen and Haug, eds., 20-43.

Jones, P. V. 1988. Homer's Odyssey: A Companion to the English Translation of Richmond Lattimore. Bristol.

Jong, I. J. F. de. 1990. “Three Off-Stage Characters in Euripides.” Mnemosyne 43: 1-21.

Jong, I. J. F. de. 1991. "Narratology and Oral Poetry: The Case of Homer.” Poetics Today 12: 40523.

Jong, I. J. F. de. 1997. “Homer and Narratology.” In Morris and Powell, eds., 305-25.

Jong, I. J. F. de. 2001. A Narratological Commentary on the Odyssey. Cambridge.

Jong, I. J. F. de. 2002. "Developments in Narrative Technique in the Odyssey." In Epea pteroenta. Beiträge zur Homerforschung. Festschrift für Wolfgang Kullmann zum 75. Geburtstag, edited by M. Reichel and A. Rengakos, 77-91. Stuttgart.

Jong, I. J. F. de. 2004. "Homer." In Narrators, Narratees, and Narratives in Ancient Greek Literature: Studies in Ancient Greek Narrative vol. 1, edited by I. J. F. de Jong, R. Nünlist, and A. Bowie, 13-24. Leiden and Boston.

Jong, I. J. F. de. 2007. "Homer." In Time in Ancient Greek Literature: Studies in Ancient Greek Narrative vol. 2, edited by I. J. F. de Jong and R. Nünlist, 17-37. Leiden and Boston.

Jong, I. J. F. de. 2014. Narratology and the Classics: A Practical Guide. Oxford. 
Köhnken, A. 2014. “Apollonius' Argonautica.” In A Companion to Hellenistic Literature, edited by J. J. Clauss and M. Cuypers, 136-50. Malden, MA.

Lowe, N. J. 2000. The Classical Plot and the Invention of Western Narrative. Cambridge.

Macleod, C. W. 1982. Homer: Iliad, Book XXIV. Cambridge.

Marks, J. 2008. Zeus in the Odyssey. Cambridge, MA and London.

Montanari, F., Rengakos, A. and Tsagalis, C., eds. 2012. Homeric Contexts: Neoanalysis and the Interpretation of Oral Poetry $=$ Trends in Classics Supplementary Volume 12. Berlin and Boston.

Morris, I. and Powell, B., eds. 1997. A New Companion to Homer. Leiden.

Nagy, G. 1979. The Best of the Achaeans: Concepts of the Hero in Archaic Greek Poetry. Baltimore.

Nünlist, R. 2009. The Ancient Critic at Work. Terms and Concepts of Literary Criticism in Greek Scholia. Cambridge.

Page, D. L. 1955. The Homeric Odyssey. Oxford.

Polinskaya, I. 2011. "Peleus.” In The Homer Encyclopedia, edited by M. Finkelberg, vol. 2: 637-9. Malden, MA.

Pucci, P. 1987. Odysseus Polutropos: Intertextual Readings in the Odyssey and the Iliad. Ithaca, NY.

Reece, S. 1994. "The Cretan Odyssey: A Lie Truer than Truth.” AJPh 115: 157-73.

Rengakos, A. 2002. "Narrativität, Intertextualität, Selbstreferentialität: die neue Deutung der Odyssee.” In Epea pteroenta. Beiträge zur Homerforschung. Festschrift für Wolfgang Kullmann zum 75. Geburtstag, edited by M. Reichel and A. Rengakos, 173-91. Stuttgart.

Rengakos, A. 2015. "Narrative Techniques in the Epic Cycle.” In Fantuzzi and C. Tsagalis, eds., 154-63.

Richardson, N. J. 1993. The Iliad: A Commentary, Vol. 6: Books 21-24. Cambridge.

Richardson, S. 1990. The Homeric Narrator. Nashville. 
Rutherford, R. B. 2001. "From the Iliad to the Odyssey." In Oxford Readings in Homer's Iliad, edited by D. L. Cairns, 117-46. Oxford. First published in BICS 38 (1991-1993): 47-54.

Rutherford, R. B. 2013. Homer. Cambridge.

Saï, S. 2011. Homer and the Odyssey.

Schein, S. L. 1997. “The Iliad: Structure and Interpretation.” In Morris and Powell, eds., 345-59.

Schein, S. L. 2016. "Homeric Intertextuality: Two Examples." In Homeric Epic and its Reception: Interpretative Essays, S. L. Schein, 81-91. Oxford.

Schmitz, T. A. 2007. "The Use of Analepses and Prolepses in Quintus Smyrnaeus' Posthomerica." In Quintus Smyrnaeus: Transforming Homer in Second Sophistic Epic, edited by M. Baumbach and S. Bär, 65-84. Berlin and New York.

Scodel, R. 2008. “Zielinski’s Law Reconsidered.” TAPhA 138: 107-25.

Steiner, D. 2010. Homer Odyssey Books XVII and XVIII. Cambridge.

Tsagalis, C. 2012. "Deauthorizing the Epic Cycle: Odysseus' False Tale to Eumaeus (Od. 14.199359).” In Montanari, Rengakos and Tsagalis, eds., 309-45.

Usener, K. 1990. Beobachtungen zum Verhältnis der Odyssee zur Ilias. Tübingen.

Wachter, R. 2012. "The Other View: Focus on Linguistic Innovations in the Homeric Epics.” In Andersen and Haug. eds., 65-79.

West, M. L. 2001. Studies in the Text and Transmission of the Iliad. Leipzig and Munich.

West, M. L. 2006. “Archilochus and Telephos.” ZPE 156: 11-17.

West, M. L. 2011. The Making of the Iliad: Disquisition and Analytical Commentary. Oxford.

West, M. L. 2013. The Epic Cycle: A Commentary on the Lost Troy Epics. Oxford.

West, M. L. 2014. The Making of the Odyssey. Oxford. 
West, S. R. 1989. “Laertes Revisited.” PCPS 35: 113-43. 